\title{
COLLAGEN PROFILE AND TENDERNESS OF STRIP LOIN AND SILVERSIDE ORIGINATED FROM POLISH HOLSTEIN-FRIESIAN BULLS OF THE BLACK AND WHITE VARIETY
}

\author{
A. SzaŁkowska ${ }^{\mathrm{a}}$ and M. ModzelewSKa-KapituŁa ${ }^{\mathrm{b} *}$ \\ ${ }^{a}$ Department of Meat Technology and Chemistry, \\ ${ }^{b}$ Department of Industrial Commodity, Basics of Techniques and Energy Management, Faculty of Food Sciences, \\ University of Warmia and Mazury in Olsztyn, Plac Cieszyński 1, 10-719 Olsztyn. Poland
}

(Received: 18 May 2015; accepted: 19 July 2015)

\begin{abstract}
The aim of the study was to determine and compare the collagen profile of two beef carcass cuts: silverside ( $M$. semitendinosus) and strip loin (M. longissimus lumborum), originated from Polish Holstein-Friesian bulls of the black and white variety. Silverside showed higher total, acid-soluble, total soluble, and insoluble collagen content than strip loin. Significant differences between silverside and strip loin were noted in their share of water-soluble and acid-soluble collagen ( $\%$ total collagen, $\mathrm{P}<0.05$ ). The thermal treatment caused cooking losses, which reached $38 \%$ in strip loin and $40 \%$ in silverside. There were no significant differences in shear force values or organoleptic quality between the cuts, which indicates their similar usefulness as meat for roasting. The content and profile of intramuscular collagen did not influence the organoleptic quality or shear force values of silverside and strip loin.
\end{abstract}

Keywords: beef, bulls, collagen, thermal treatment

In the skeletal muscles, the connective tissue is present in the form of epi-, peri-, and endomysium and muscle fascia (PURsLow, 2014). The connective tissue is composed of three primary proteins: collagen, elastin, and reticulin. Collagen, located in the proteoglycans matrix, is the protein whose proportion in the connective tissue is the highest (PuRsLow, 2014). In muscle tissue, the average collagen content ranges from $1 \%$ to $6 \%$ of protein and depends on many factors, such as muscle type and the sex and diet of animals (PursLow, 2005; DuBost et al., 2013). Different muscles obtained from the same carcass have different collagen content and solubility, which is determined by the location of the muscle in a carcass and its activeness during the animal's life (JEREMiAH et al., 2003a). In the muscles that worked harder during the animal's life, the collagen content is higher compared to the less active muscles (Jeremiah et al., 2003a). In the carcasses of highly muscled cattle, thin, tightly packed muscle fibres are present, which prevents them from accumulating higher quantities of collagen (MAHER et al., 2004). The animal's age mainly causes a decrease in water-soluble collagen percentage and an increase in insoluble collagen (SERRA et al., 2008; SCHÖNFELDT \& STRYDOM, 2011).

In Poland, the most popular cattle breed is Holstein-Friesian, which is represented by $90 \%$ of livestock (IwanowsKa \& Pospiech, 2010). Despite the fact that it is a dairy breed,

\footnotetext{
* To whom correspondence should be addressed. Phone:+48-89-523 33 37; e-mail: monika.modzelewska@uwm.edu.pl
} 
increased interest in its slaughter value is noted due to the fact that young bulls show satisfactory daily body mass gain from 0.8 to $1.2 \mathrm{~kg}$ and dressing percentage from $55 \%$ to 57\% (NoGALSKI et al., 2014; WAJDA et al., 2014). Most frequently, Holstein-Friesian cattle are analysed by their dairy purpose. The evaluation of the breed's slaughter value concerns the dressing percentage and the EUROP classification, although there is a lack of information on muscle collagen profile and concentration, and other quality attributes of the meat obtained from the cattle. Thus, the aim of the study was to determine collagen content and solubility in roasted M. semitendinosus and longissimus lumborum, offered on the market as silverside and strip loin, obtained from young Polish Holstein-Friesian bulls, and to evaluate selected quality attributes of the meat.

\section{Materials and methods}

The material comprised $M$. longissimus lumborum (LL, strip loin, $\mathrm{n}=5$ ) and $M$. semitendinosus (ST, silverside, $\mathrm{n}=5$ ), obtained from Polish Holstein-Friesian bulls at the age of 18 months slaughtered on the same day. The muscles were cut from cooled carcasses $96 \mathrm{~h}$ after slaughter. The muscles were subjected to thermal treatment after 5 days of post mortem ageing, in a convection-steam oven (Küppersbusch CPE 110, Küppersbusch Großküchentechnik GmbH, Gelsenkirchen, Germany) at $180{ }^{\circ} \mathrm{C}$ to obtain $80{ }^{\circ} \mathrm{C}$ in the muscle centre. After thermal treatment the muscles were cooled at room temperature (approx. $20^{\circ} \mathrm{C}$ ), and then to $3 \pm 2{ }^{\circ} \mathrm{C}$ in a refrigerator. After cooling, the muscles were weighted and samples for sensory evaluation (fragments approx. $4 \mathrm{~cm}$ long) were cut. Next, the outer crusted surface of the muscles was removed using a knife, and samples for Warner-Bratzler shear force determination were cut (diameter $1.3 \mathrm{~cm}, 4 \mathrm{~cm}$ long, $\mathrm{n}=5$ for each muscle, $\mathrm{n}=50$ in total). Then, the meat, including the earlier cut crusted surface, was ground using a $3 \mathrm{~mm}$ size mesh. Cooking loss and WarnerBratzler shear force (Instron 5965, Instron, Norwood, MA, USA) at $2 \mathrm{~mm} \mathrm{~s}^{-1}$ shear device speed were determined. Sensory evaluation was conducted on $2 \mathrm{~mm}$-thin slices (Ma-Ga S 712p, Bydgoskie Zakłady Maszyn Gastronomicznych, Bydgoszcz, Poland) by six panellists using a 1 to 9 point scale for tenderness (1: very tough; 9: extremely tender), juiciness (1: extremely dry; 9: extremely juicy), taste (1: bland, atypical; 9: intense, typical), aroma (1: very weak, atypical; 9: extremely intense, typical), and overall liking (1: not acceptable; 9: extremely acceptable). Total collagen (REICH, 1970), water-soluble (HiLl, 1966) and insoluble (MoDZELEWSKA-KAPITUŁA et al., 2015) collagen contents were determined ( $\mathrm{n}=3$ for each muscle sample) based on hydroxyproline content (BlOMFIELD \& FARRAR, 1964). Acidsoluble collagen content was calculated as a difference between total collagen and the sum of water-soluble and insoluble collagen content, while total soluble collagen content was calculated as a sum of water-soluble and acid-soluble collagen contents. The statistical model was composed on the grouping variable, which was muscle (2 levels: LL and ST) and the dependent variables (16 levels: cooking loss, WBSF, total collagen (mg/100 g), water-soluble collagen (mg/100 g, \%), acid-soluble collagen (mg/100 g, \%), total soluble collagen (mg/100 $\mathrm{g}, \%$ ), insoluble collagen (mg/100 g, \%), tenderness, juiciness, taste, aroma, overall liking). The results were subjected either to variance analysis (cooking loss, WBSF, insoluble collagen content and proportion) or the Mann-Whitney U-test (sensory attributes, total, water-soluble, acid-soluble, total soluble collagen content and proportion) at $\mathrm{P}=0.05$ based on the results of Shapiro-Wilk's and Leven's tests (Statistica 10, StatSoft Inc., Tulsa, OK, USA). 


\section{Results and discussion}

The thermal treatment used in the study caused relatively high cooking losses (Table 1), similar for both muscles $(\mathrm{P}>0.05)$. Cooking loss depends on many factors, such as thermal treatment method, final internal temperature of the meat, and its chemical composition (JEREMIAH et al., 2003b). The cooking loss for LL and ST muscles noted in the present study was similar to that noted by PALKA (2003) for ST muscle heated to $80^{\circ} \mathrm{C}$.

Table 1. Warner-Bratzler shear force values, cooking loss, and collagen content in roasted beef

\begin{tabular}{|c|c|c|c|c|c|}
\hline \multirow[t]{2}{*}{ Attribute } & \multicolumn{2}{|c|}{$\begin{array}{c}\text { Silverside } \\
(M . \text { semitendinosus })\end{array}$} & \multicolumn{2}{|c|}{$\begin{array}{c}\text { Strip loin } \\
\text { (longissimus lumborum) }\end{array}$} & \multirow{2}{*}{$\begin{array}{c}\text { Significance } \\
\text { (P-value) }\end{array}$} \\
\hline & $\mathrm{x}$ & SD & $\mathrm{x}$ & SD & \\
\hline Cooking loss ( $\%)$ & 39.8 & 1.62 & 37.96 & 2.39 & NS \\
\hline Shear force $(\mathrm{N})$ & 80.65 & 6.53 & 80.59 & 8.13 & NS \\
\hline \multicolumn{6}{|c|}{ Collagen (mg/100 g) } \\
\hline Total & 1519.3 & 238.9 & 1256.6 & 315.8 & 0.000 \\
\hline Water soluble & 357.0 & 198.8 & 424.6 & 220.8 & NS \\
\hline Acid-soluble & 871.0 & 224.8 & 575.0 & 230.7 & 0.000 \\
\hline Total soluble & 1228.0 & 181.8 & 999.6 & 184.5 & 0.000 \\
\hline Insoluble & 266.0 & 43.6 & 192.9 & 50.0 & 0.000 \\
\hline \multicolumn{6}{|c|}{ Collagen ( $\%$ of total collagen) } \\
\hline Water-soluble & 23.6 & 13.5 & 34.1 & 18.1 & 0.031 \\
\hline Acid-soluble & 57.9 & 15.3 & 47.2 & 20.6 & 0.033 \\
\hline Total soluble & 81.6 & 10.7 & 81.3 & 12.1 & NS \\
\hline Insoluble & 17.8 & 3.2 & 16.2 & 5.8 & NS \\
\hline
\end{tabular}

$\mathrm{x}$ : mean value; SD: standard deviation; differences significant at the level of $\mathrm{P}<0.05$; NS: no significant differences at $\mathrm{P}=0.05$

Roasted ST and LL muscles did not differ significantly $(\mathrm{P}>0.05)$ in WBSF values (Table 1). The results, which indicated a lack of differences between LL and ST muscles in WBSF values, are in agreement with those reported by DOMARADZKI and co-workers (2013), but fail to support the findings of ZAJĄC and co-workers (2011), who noted higher WBSF values for LL than ST muscle. Both muscles showed relatively high WBSF values (approx. $81 \mathrm{~N}$ ). Lower WBSF values were reported by PALKA (2003) for roasted ST steaks (approx. $62 \mathrm{~N}$ ). On the other hand, THERKILDSEN and co-workers (2008) reported also high WBSF values for LL muscles obtained from Holstein-Friesian young bulls after 2 days of ageing (approx. 85 N). Results obtained indicate that meat obtained from Polish Holstein-Friesian bulls needs more than 5 days of post mortem ageing to tenderize.

LL muscle showed lower $(\mathrm{P}<0.05)$ total, acid-soluble, total soluble, and insoluble collagen contents than ST muscle, whereas ST muscle showed a higher percentage of acidsoluble collagen ( $\%$ of total) and lower water-soluble collagen ( $\%$ of total) contents than LL 
muscle $(\mathrm{P}<0.05$, Table 1). There were no differences between the muscles in terms of insoluble and total soluble collagen percentages. During thermal treatment, collagen fibres are destroyed as a result of the thermal hydrolysis of collagen. Tropocollagen molecules break down mainly into three constituents: $\alpha, \beta$, and $\gamma$, among which $\alpha$-constituents are soluble in water and inert salts solutions, while the remaining $(\beta$ and $\gamma)$ solubilise in $0.5 \mathrm{M}$ $\mathrm{CH}_{3} \mathrm{COOH}$ (REICH, 1970). In the present study, soluble collagen accounted for over $80 \%$ of total collagen. This indicates a low degree of collagen cross-linking, which is typical for meat obtained from young animals. The results of this study are in line with those of ZAJAc and co-workers (2011) and DomARADZKi and co-workers (2013), who found that ST muscle had higher total collagen content than LL muscle. KwIATKOwSKA and co-workers (2010) reported a lack of difference between LL and ST muscles in insoluble collagen content, which is in accordance with our findings. The total collagen content noted in the present study was similar to that reported by DOMARADZKI and co-workers (2013) in LL and ST muscles (1403 $\mathrm{mg} / 100 \mathrm{~g}$ and $1936 \mathrm{mg} / 100 \mathrm{~g}$, respectively), obtained from the carcasses of young HolsteinFriesian Black and White variety bulls. However, the results of the present study concerning total and insoluble collagen content in LL muscle were higher than those reported by ChristensEn and co-workers (2011) for meat obtained from beef breeds. Average total collagen content in LL muscle was $287 \mathrm{mg} / 100 \mathrm{~g}$ for Limousine and $368 \mathrm{mg} / 100 \mathrm{~g}$ for Charolais; insoluble collagen contents were 215 and $278 \mathrm{mg} / 100 \mathrm{~g}$, respectively (CHRISTENSEN et al., 2011).

Roasted LL and ST muscles did not differ in any sensorial attribute $(\mathrm{P}>0.05)$. The lack of significant differences in sensorial tenderness between LL and St muscles is in agreement with the results of instrumental measurements of tenderness (WBSF). Both muscles were rated relatively high in sensorial assessment (average values for all attributes ranged from 7.9 (ST aroma) to 6.6 (juiciness of LL and ST) in 9 point scale. The good eating quality of meat obtained from young Polish Holstein-Friesian bulls has also been reported by WAJDA and coworkers (2014).

Although LL muscle had lower total and insoluble collagen content than ST muscle, it did not produce differences in tenderness between the muscles. However, reports concerning the influence of collagen on meat tenderness are ambiguous. JEREMIAH and co-workers (2003b) showed that total and insoluble collagen contents were negatively correlated with sensorial tenderness, while CHRIKI and co-workers (2013) noted a positive correlation between WBSF values and total and insoluble collagen content. On the other hand, Christensen and co-workers (2011) found that the concentration of particular collagen fractions in LL muscle was not correlated significantly with WBSF values. DuBost and coworkers (2013) reported positive correlations between total collagen and sensorial tenderness, as well as insoluble collagen content and aroma acceptability.

\section{Conclusions}

Longissimus lumborum and semitendinosus muscles obtained from the carcasses of young Polish Holstein-Friesian bulls differed in total collagen and particular collagen fractions. After thermal treatment a higher content of collagen content was found in semitendinosus muscle. There were no differences in total soluble and insoluble collagen content between the muscles, which indicates similar degrees of cross-linking in collagen fibres. Longissimus lumborum and semitendinosus muscles did not differ in terms of cooking loss, shear force, or 
eating quality, which indicates their similar usefulness as meat for roasting. Collagen content and solubility of the muscles did not affect their sensorial or instrumental tenderness. The meat from Polish Holstein-Friesian bulls should be subjected to longer than 5 days post mortem ageing to tenderize.

This study was conducted within the Project no. WND-POIG.01.03.01-00-204/09 Optimizing of Beef Production in Poland According to "From Fork to Farm" strategy, co-financed by the European Regional Development Fund under the Innovative Economy Operational Program 2007-2013.

\section{References}

Blomfield, L.J. \& FarRaR, F. (1964): Factors affecting the determination of hydroxyproline. Anal. Chem., 20, 950954.

Chriki, S., Renand, G., Picard, B., Micol, D., Journaux, L. \& Hocquette, J.F. (2013): Meta-analysis of the relationship between beef tenderness and muscle characteristics. Meat Sci., 155, 424-434.

Christensen, M., Ertbjerg, P., Failla, S., Sañudo, C., Richardson, R.I., Nute, G.R., Olleta, J.L., Panea, B., Albertí, P., Juárez, M., Hocquette, J.-F. \& Williams, J.L. (2011): Relationship between collagen characteristics, lipid content and raw and cooked texture of meat from young bulls of fifteen European breeds. Meat Sci., 87, 61-65.

DomaradzKi, P., FloreK, M. \& LitwińczuK, A. (2013): Zawartość kolagenu ogólnego i rozpuszczalnego w mięśniach szkieletowych różnych kategorii bydła rasy polskiej Holsztyńsko-fryzyjskiej (Total and soluble collagen contents in skeletal muscles of different cattle categories of Polish Holstein-Friesian breed). Episteme, 21, $177-185$.

Dubost, A., Micol, D., Meunier, B., Lethias, C. \& Listrat, A. (2013): Relationship between structural characteristics of bovine intramuscular connective tissue assessed by image analysis and collagen and proteoglycan content. Meat Sci., 93, 378-386.

HiLL, F. (1966): The solubility of intramuscular collagen in meat animals of various ages. J. Food Sci., 31, 161-166.

IWANOWSKA, A. \& Pospiech, E. (2010): Comparison of slaughter value and muscle properties of selected cattle breeds in Poland - review. Acta Scient. Pol. Technol. Aliment., 9, 7-22.

Jeremiah, L.E., Dugan, M.E.R., Aalhus, J.L. \& Gibson, L.L. (2003a): Assessment of the chemical and cooking properties of the major beef muscles and muscle groups. Meat Sci., 65, 985-992.

Jeremiah, L.E., Dugan, M.E.R., Aalhus, J.L. \& Gibson, L.L. (2003b): Assessment of the relationship between chemical components and palatability of major beef muscles and muscle groups. Meat Sci., 65, 1013-1019.

Kwiatkowska, A., Dąbrowska, E. \& Modzelewska-KapituŁa, M. (2010): Profil kolagenu mię̧́ńniowego wybranych surowych i pieczonych elementów wołowiny kulinarnej i jego wpływ na teksturę (The profile of muscular collagen in raw and roasted beef and its influence on meat texture). Zesz. Probl. Post. Nauk Rol., 546, 207212.

Maher, S.C., Mullen, A.M., Keane, M.G., Buckley, D.J., Kerry, J.P. \& Moloney, A.P. (2004): Variation in the eating quality of M. longissimus dorsi from Holstein-Friesian bulls and steers of New Zealand and European/ American descent, and Belgian Blue $\times$ Holstein-Friesians, slaughtered at two weights. Livest. Prod. Sci., 90, $271-277$.

Modzelewska-Kapitula, M., Kwiatkowska, A., Jankowska, B. \& Dabrowska, E. (2015): Water holding capacity and collage profile of bovine $m$. infraspinatus during postmortem ageing. Meat Sci., 100, 209-216.

Nogalski, Z., Wielgosz-Groth, Z., Purwin, C., Nogalska, A., Sobczuk-Szul, M., Winarski, R. \& Pogorzelska, P. (2014): The effect of slaughter weight and fattening intensity on changes in carcass fatness in young HolsteinFriesian bulls. Ital. J. Anim. Sci., 13, 66-72.

PALKA, K. (2003): The influence of post-mortem ageing and roasting on the microstructure, texture and collagen solubility of bovine semitendinosus muscle. Meat Sci., 64, 191-198.

PursLow, P.P. (2005): Intramuscular connective tissue and its role in meta quality. Meat Sci., 70, 435-447.

PuRsLow, P.P. (2014): New developments on the role of intramuscular connective tissue in meat toughness. Аnпи. Rev. Food Sci. T., 5, 8.1-8.21.

Reich, G. (1970): Kolagen. Zarys metod. Wyniki i kierunki badania (Collagen. Methods, results and directions of the research). WNT, Warszawa, 368 pages. 
SchöNfeldt, H.C. \& Strydom, P.E. (2011): Effect of age and cut tenderness of South African beef. Meat Sci., 87, $206-218$

Serra, X., Guerrero, L., Guárdia, M.D., Gil, M., Sañudo, C., Panea, B., Campo, M.M., Olleta, J.L., GarcíaCAchán, M.D., Piedrafita, J. \& Oliver, M.A. (2008): Eating quality of young bulls from three Spanish beef breed-production systems and its relationships with chemical and instrumental meat quality. Meat Sci., 79, 98-104.

Therkildsen, M., Houbak, M.B. \& Byrne, D.V. (2008): Feeding strategy for improving tenderness has opposite effects in two different muscles. Meat Sci., 80, 1037-1045.

WaJda, S., Kondratowicz, J., BURCZyK, E. \& WinARSKI, R. (2014): Wydajność rzeźna i jakość mięsa tusz buhajków zakwalifikowanych w systemie EUROP do różnych klas uformowania (Slaughter value and quality of meat from beef carcasses classified to different conformation classes in EUROP system). Żywność. Nauka. Technol. Jakość, 95(4), 136-147.

Zając, M., Midura, A., Palka, K., Węsierska, E. \& Krzysztoforski, K. (2011): Skład chemiczny, rozpuszczalność kolagenu śródmięśniowego i tekstura wybranych mięśni wołowych (Chemical composition, solubility of intramuscular collagen, and texture of selected beef muscles). Żywność. Nauka. Technol. Jakość, 77(4), 103116. 